\title{
Bush backs Bement to head science agency
}

Geoff Brumfiel, Washington

Arden Bement, a metallurgist with a strong track record in industry, government and the academic world, has been nominated by the US president, George W. Bush, to serve as the National Science Foundation's twelfth director.

Bement is currently director of the National Institute of Standards and Technology (NIST), but has been doing double duty as acting director of the US science agency since marine biologist Rita Colwell stepped down in February (see Nature 427, 665; 2004).

The 15 September nomination was made three days before a legal deadline for nominating a permanent director. It awaits confirmation by the Senate.

Bush put Bement's name forward after months of fruitless searching for a permanent replacement for Colwell, observers say. The search was hampered by uncertainty ahead of November's presidential election, as candidates did not know which president they would be serving - or even whether their nomination would stand if Bush lost.

The National Science Foundation is the main US funding agency for university research in disciplines other than biomedical science. Its directors are often chosen for

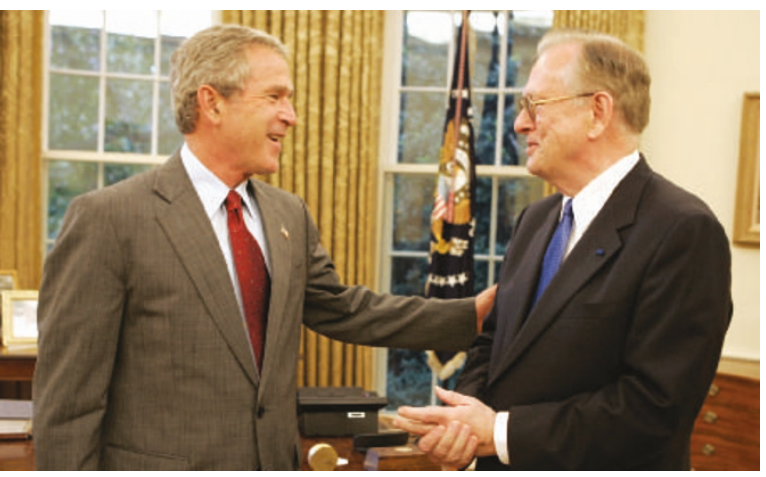

US President Bush greets Arden Bement, who supporters hope will 'get things done' at the National Science Foundation.

at the Defense Advanced Research Projects Agency and served briefly, in 1979 , as head of research and development at the Pentagon.

"I'm quite eager to accept this responsibility," Bement says. As director of the agency, he adds, he will work to bring more women and members of minority groups to the sciences. In addition, he hopes to increase the success rate for grant applications.

$\mathrm{He}$ also hopes to take up the appointment whoever wins the election. "Historically, the foundation has responded to the needs of science, regardless of the administration," he

their administrative experience: Colwell, an accomplished scientist with big ideas for the agency's expansion, was an exception.

Supporters of the agency are upbeat about 72-year-old Bement's appointment. "He's a team player who knows how to get things done within the government," one science lobbyist said.

Before his four-year stint as director of NIST, Bement was head of the nuclear engineering department at Purdue University, Indiana, and had previously run research and development at TRW, a major military contractor. He is no stranger to Washington, having led the materials science programme says. "I would want to preserve this tradition."

No serious opposition to Bement is likely in the Senate, but when the nomination will be confirmed remains uncertain. Congress is on a shortened schedule and is struggling to deal with more pressing nominations, and Democrats may seek to block new appointments until after the election, in case Kerry wins and wants to make his own choices.

"It is still possible that we could do the confirmation this year," says Gayle Osterberg, a Senate spokeswoman. But others are less sanguine. "I don't know if we would confirm a dog catcher right now," opines another Senate staffer.

\section{Hurricane Ivan highlights future risk for New Orleans}

\section{Tony Reichhardt, Washington}

Tropical storms and hurricanes have surged through much of the Caribbean this month, leaving hundreds dead in flooded Haiti, devastating several other islands and causing havoc along parts of the US coast.

But scientists say that another disaster was only narrowly avoided - Hurricane Ivan missed the deeply vulnerable city of New Orleans by a tiny margin. In the face of future such storms, they are calling for action to restore the area's wetlands, to act as a barrier against flooding.

The Louisiana city was directly in Ivan's path on 14 September, when the storm was classed as 'Category 5' with winds upward of 240 kilometres per hour. Almost a million people were evacuated. But Ivan's centre came ashore more than $\mathbf{1 6 0}$ kilometres east of New Orleans on 16 September, and no major flooding was reported in the city.

Scientists warn that a storm is bound to hit New Orleans at some point in the near future, however. Simulations run by the Center for the Study of Public Health Impacts of Hurricanes at Louisiana State University in

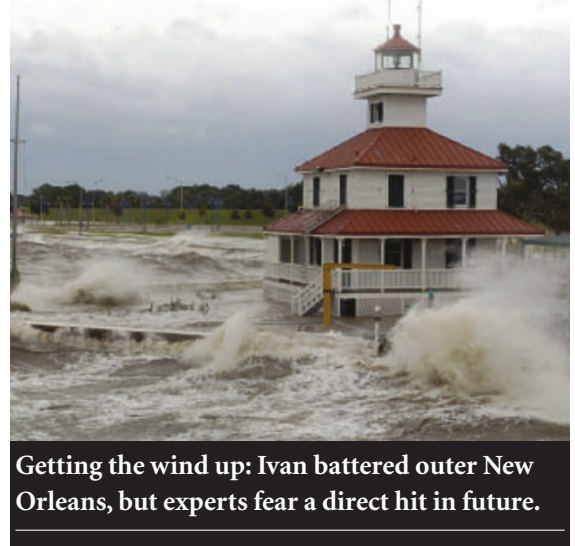

Baton Rouge show that direct hits by even Category 3 storms would have disastrous consequences. Storm surges could flood the city, which lies in a basin mostly below sea level, to a depth of six metres. This would take weeks to drain. "You're talking about total destruction," says the centre's director Ivor van Heerden, claiming that deaths could be in the tens of thousands.

Greg Stone, director of the Coastal Studies Institute at Louisiana State
University, thinks the city's levees would hold after an assault from a Category 3 hurricane - but not from a Category 4 or 5 storm. Both scientists agree that the mayor was correct in urging the city's 1.3 million residents to flee.

Restoring barrier reefs and marshlands in the delta between the city and the Gulf of Mexico is the best way to mitigate the threat, the researchers say. The wetlands have been steadily eroded since the 1930s owing to extensive embankments built to control flooding of the Mississippi river. These prevent water and sediment from reaching the delta. "We are literally starving our wetlands to death," says van Heerden.

A 30-year restoration plan, called Coast 2050, was published in 1998. But arguments over who should foot the \$14-billion bill have stalled the plan in Congress ever since. Stone and other scientists were planning to brief Louisiana's congressional delegation on coastal restoration this week.

The hurricane season, which is currently at the peak of a 30-40 year cycle, is expected to continue for a few more months. 